\title{
Declining Sensitivity to Interleukin 3 of Murine Multipotential Hemopoietic Progenitors during Their Development Application to a Culture System That Favors Blast Cell Colony Formation
}

Kenichi Koike, James N. lhle, and Makio Ogawa

Department of Medicine, Medical University of South Carolina and Veterans Administration Medical Center, Charleston, South Carolina 29403; and Biological Carcinogenesis Program, National Cancer Institute-Frederick Cancer Research Facility,

Frederick, Maryland 21701

\begin{abstract}
When spleen cells of 5-fluorouracil (5-FU)-treated mice were cultured in the presence of interleukin 3 (IL-3), most colonies revealed IL-3 concentration-dependent colony formation except for mast cell colonies and blast cell colonies. While most colonies were smaller in lower concentrations of IL-3, the size of the blast cell colonies were similar between high and low IL-3 groups. These data suggested that blast cell colony development requires less IL-3 than the development of multilineage colonies from blast cell colonies. This notion was supported by experiments in which IL-3 was added twice to cultures of spleen cells of 5-FUtreated mice. When low concentrations of IL-3 were added on day 7 , there was a reduction in the number of multilineage colonies formed without an effect on the number of blast cell colonies. Using this information, we developed a culture system that favors blast cell colony formation by cells of normal mice. When low $(20 \mathrm{U} / \mathrm{ml})$ concentrations of IL-3 were added to cultures of spleen cells of normal mice on day 7 of incubation in media containing 2-5\% fetal calf serum, blast cell colonies were the predominant colony type. The blast cell colonies revealed high but variable secondary replating efficiencies. These data suggest that multipotential progenitors may become less sensitive to IL-3 as they differentiate in culture.
\end{abstract}

\section{Introduction}

Hemopoietic blast cell colonies have high replating ability and self-renewal capacities (1) and promise to be important for studies of the mechanisms of proliferation and differentiation of early hemopoietic progenitors. For example, analysis of the distribution of cells forming secondary blast cell colonies from individual primary blast cell colonies has suggested a stochastic mechanism of self-renewal of multipotential progenitors in culture (2), consistent with earlier studies of spleen colony-forming units (CFU-S) (3). Studies of individual cells isolated from blast cell colonies have suggested that differentiation is also a stochastic

\section{Address reprint requests to Dr. Ogawa, VA Medical Center. \\ Received for publication 16 September 1985 and in revised form 18 November 1985.}

1. Abbreviations used in this paper: B, erythroid bursts; BL, blast cell colonies; CFU-S, colony-forming units in spleen; EM, erythrocytemegakaryocyte colonies; EP, erythropoietin; FCS, fetal calf serum; 5-FU, 5-fluorouracil; GEM, granulocyte-erythrocyte-macrophage colonies; GEMM, granulocyte-erythrocyte-macrophage-megakaryocyte colonies; GMM, granulocyte-macrophage-megakaryocyte colonies; IL-3, interleukin 3; MAST, mast cell colonies.

The Journal of Clinical Investigation, Inc.

Volume 77, March 1986, 894-899 process in which stem cells randomly become restricted in lineage potentials (4-6). More recently, studies of the effects of interleukin 3 (IL-3) on blast cell colony formation suggested that IL3 provides a permissive milieu for the proliferation of early progenitors in culture but does not trigger stem cells in $\mathrm{G}_{0}$ to begin proliferation (7).

A drawback in the use of blast cell colonies is their low incidence, which makes it extremely difficult to identify them in cultures of normal cells. Only 1-2 blast cell colonies may be identified in a dish containing many large and often macroscopic mixed hemopoietic colonies (1). Pretreatment of mice by injection of high-dose 5-fluorouracil (5-FU) significantly enriches marrow and spleen cells for blast cell colony-forming units (8). However, exposure to cancer chemotherapeutic agents may make these colonies undesirable for certain types of experiments. Earlier we reported on the cell-cycle dormancy of progenitors for blast cell colonies and the absence of the requirement for IL-3 by these cells (7). In contrast, maturer hemopoietic progenitors that are more active in cell division are known to require constant availability of specific colony-stimulating factors. Our recent studies of hemopoietic progenitors in serum-free culture have provided preliminary information that blast cell colony formation may require less IL-3 than multilineage colony formation (9). In the current investigation, we extended this observation and applied the concept to development of a culture system that favors blast cell colony formation by cells of normal mice.

\section{Methods}

Purified IL-3. IL-3 has been purified to homogeneity as previously described (10). A stock solution containing $40,000 \mathrm{U} / \mathrm{ml}$ was kept frozen in phosphate-buffered saline containing $1 \%$ crystallized bovine serum albumin (BSA) (Sigma Chemical Co., St. Louis, MO).

Cell preparation. We used 10-15-wk-old female $\mathrm{BDF}_{1}$ mice that had been obtained from Simonsen's Laboratory, Gilroy, CA. Single cell suspensions were prepared from pooled spleens of 3-5 mice. 5-FU (Adria Laboratories, Inc., Columbus, $\mathrm{OH}$ ) was administered intravenously through the tail vein of mice at a dosage of $150 \mathrm{mg} / \mathrm{kg}$ body weight (11) Spleen cells were harvested $4 \mathrm{~d}$ after 5-FU injection.

Clonal cell cultures. Cultures were carried out in 35-mm Lux suspension culture dishes (5221R, Miles Laboratories, Inc., Naperville, IL) by using a modification $(1,12)$ of the technique described by Iscove et al. (13). Unless otherwise specified, $1 \mathrm{ml}$ of culture consisted of $1 \times 10^{6}$ spleen cells from normal or 5-FU-treated mice, $\alpha$-medium (Flow Laboratories, Inc., Rockville, MD), 1.2\% methylcellulose (Fisher Scientific Co., Norcross, GA), 30\% fetal calf serum (FCS) (Flow Laboratories, Inc.), $1 \%$ crystallized and deionized BSA, $10^{-4} \mathrm{M}$ mercaptoethanol (Eastman Organic Chemicals, Rochester, NY), 2 of partially purified human urinary erythropoietin (EP) with a specific activity of $370 \mathrm{U} / \mathrm{mg}$ protein (kindly provided by Dr. Makato Kawakita, Kumamoto University Medical School, Kumamoto, Japan), and 200 U IL-3. Low serum culture contained 2 or $5 \%$ FCS and $300 \mu \mathrm{g} / \mathrm{ml}$ fully iron-saturated human trans- 
ferrin ( $\sim 98 \%$ pure, Sigma Chemical Co.), $160 \mu \mathrm{g} / \mathrm{ml}$ soybean lecithin (Sigma Chemical Co.), $96 \mu \mathrm{g} / \mathrm{ml}$ cholesterol (Sigma Chemical Co.), and $10^{-7} \mathrm{M}$ sodium selenite (Sigma Chemical Co.). Dishes were incubated at $37^{\circ} \mathrm{C}$ in a humidified atmosphere flushed with $5 \% \mathrm{CO}_{2}$ in air.

Determination of colony type and size. In routine experiments, colony types were determined by in situ observation on an inverted microscope according to the criteria described previously $(1,12,14)$. Abbreviations for the colony types were: GM, granulocyte-macrophage colonies; B, erythroid bursts; M, megakaryocyte colonies; EM, erythrocyte-megakaryocyte colonies; GMM, granulocyte-macrophage-megakaryocyte colonies; GEM, granulocyte-erythrocyte-macrophage colonies; GEMM, granulocyte-erythrocyte-macrophage-megakaryocyte colonies; BL, blast cell colonies; and MAST, mast cell colonies. In some experiments, the size of blast cell colonies was determined by counting individual cells in situ on an inverted microscope. Multilineage colonies were individually lifted by an Eppendorf micropipette, made into single cell suspensions, and divided into two aliquots. One-half of the sample was used for counting in a counting chamber and the other half for analysis of differential counts. Differentials were done on 500 cells in May-GrunwaldGiemsa-stained preparations. Abbreviations used for the description of lineages are modifications of those recommended at a workshop of a University of California at Los Angeles, CA, symposium (15).

Replating experiments. After day 16 of incubation, blast cell colonies consisting of 30-200 cells were individually lifted from methylcellulose medium and suspended in $0.1 \mathrm{ml} \alpha$-medium. The samples were gently pipetted and then individually added to $0.9 \mathrm{ml}$ standard methylcellulose culture medium containing 30\% FCS, $200 \mathrm{U} / \mathrm{ml} \mathrm{IL-3}$, and $2 \mathrm{U} / \mathrm{ml}$ EP in the culture dishes. The cultures were again thoroughly mixed by gentle pipetting and dishes incubated at $37^{\circ} \mathrm{C}$ in $5 \% \mathrm{CO}_{2}$ in air atmosphere. In order to determine the full replating potentials of blast cell colonies, we carried out "mapping" studies as described previously (8). Whenever new colonies were identified during daily counting, their locations in the dish were recorded and their subsequent growth and differentiation followed daily.

\section{Results}

IL-3 dose-response studies. First, we examined the effects of varying concentrations of IL-3 on colony formation from spleen cells of 5-FU-treated mice in culture. One-million spleen cells were cultured in the presence of serially diluted IL-3 and various types of colonies identified and scored in situ on day 16. The results are presented in Table I. As we previously reported (7), the plateau for total colony counts was seen with IL-3 at levels of 200-400 U/ml. Dilution of IL-3 was accompanied by a decrease in total colony numbers. Most of the colony types, including GEMM colonies, revealed parallel dose responses to IL3 concentrations. Linear regression analysis of the GEMM colony numbers plotted against logarithms of IL- 3 concentrations between 1.6 and $400 \mathrm{U} / \mathrm{ml}$ revealed that the lower limit of $95 \%$ confidence interval of the true regression coefficients was $>0$. This analysis provided the evidence that there is a dose relationship between GEMM colony formation and IL-3 concentrations. Similar analysis of blast cell colony formation revealed that a $95 \%$ confidence limit of the true regression coefficients include zero, indicating the lack of an IL-3 dose response.

When blast cell colonies were excluded, the majority of the colonies appeared smaller in lower concentrations of IL-3 than those in higher concentrations of IL-3. By using a counting chamber, we analyzed $18 \mathrm{GEMM}$ colonies present in four culture dishes containing $200 \mathrm{U} / \mathrm{ml} \mathrm{IL-3}$ and compared their size to GEMM colonies seen in cultures containing 6.3-25 U/ml IL3. The results presented in Fig. $1 A$ show a significant difference in the size of GEMM colonies between high and low IL-3 groups $(P<0.001$ by Wilcoxon rank-sum test). In contrast, when the
Table I. Effects of Various Concentrations of IL-3 on Colony Formation by Spleen Cells of 5-FU-treated Mice

\begin{tabular}{cllllllll}
\hline \multicolumn{7}{c}{ Colony types } & \multicolumn{7}{l}{$l$} \\
\cline { 2 - 8 } IL-3 & GM & M & GMM & GEM & GEMM & MAST & BL & Total \\
\hline$U / m l$ & & & & & & & & \\
400 & $5 \pm 2$ & $4 \pm 2$ & $5 \pm 2$ & $1 \pm 1$ & $6 \pm 2$ & $1 \pm 1$ & $1 \pm 1$ & $23 \pm 3$ \\
200 & $6 \pm 2$ & $6 \pm 2$ & $4 \pm 2$ & $1 \pm 1$ & $6 \pm 2$ & 0 & $1 \pm 1$ & $24 \pm 2$ \\
100 & $4 \pm 1$ & $5 \pm 2$ & $5 \pm 3$ & 0 & $5 \pm 2$ & $1 \pm 1$ & $1 \pm 1$ & $21 \pm 1$ \\
50 & $5 \pm 1$ & $5 \pm 2$ & $3 \pm 1$ & 0 & $5 \pm 1$ & $1 \pm 1$ & $1 \pm 1$ & $20 \pm 2$ \\
25 & $1 \pm 1$ & $5 \pm 2$ & $2 \pm 1$ & 0 & $2 \pm 1$ & $1 \pm 1$ & $3 \pm 2$ & $14 \pm 5$ \\
12.5 & $2 \pm 1$ & $2 \pm 2$ & $1 \pm 1$ & $1 \pm 1$ & $2 \pm 1$ & $1 \pm 1$ & $1 \pm 1$ & $10 \pm 1$ \\
6.3 & $2 \pm 1$ & $2 \pm 1$ & $1 \pm 1$ & 0 & $1 \pm 0$ & $1 \pm 1$ & $2 \pm 1$ & $9 \pm 3$ \\
3.1 & $1 \pm 1$ & $1 \pm 1$ & 0 & 0 & $1 \pm 1$ & 0 & $2 \pm 1$ & $5 \pm 2$ \\
1.6 & $1 \pm 1$ & 0 & 0 & 0 & $1 \pm 1$ & 0 & $1 \pm 1$ & $3 \pm 1$ \\
0.8 & 0 & $1 \pm 1$ & 0 & 0 & 0 & 0 & 0 & $1 \pm 1$ \\
0 & 0 & 0 & 0 & 0 & 0 & 0 & 0 & 0 \\
\end{tabular}

* Data represent the mean \pm SD of quadruplicate cultures containing 1 $\times 10^{6}$ cells/dish.

size of blast cell colonies was estimated in situ by counting individual cells, there was no significant difference in size between high and low IL-3 culture groups (Fig. $1 B$ ).

For analysis of secondary replating efficiencies, individual blast cell colonies were lifted from methylcellulose culture by use of an Eppendorf micropipette and plated in the presence of

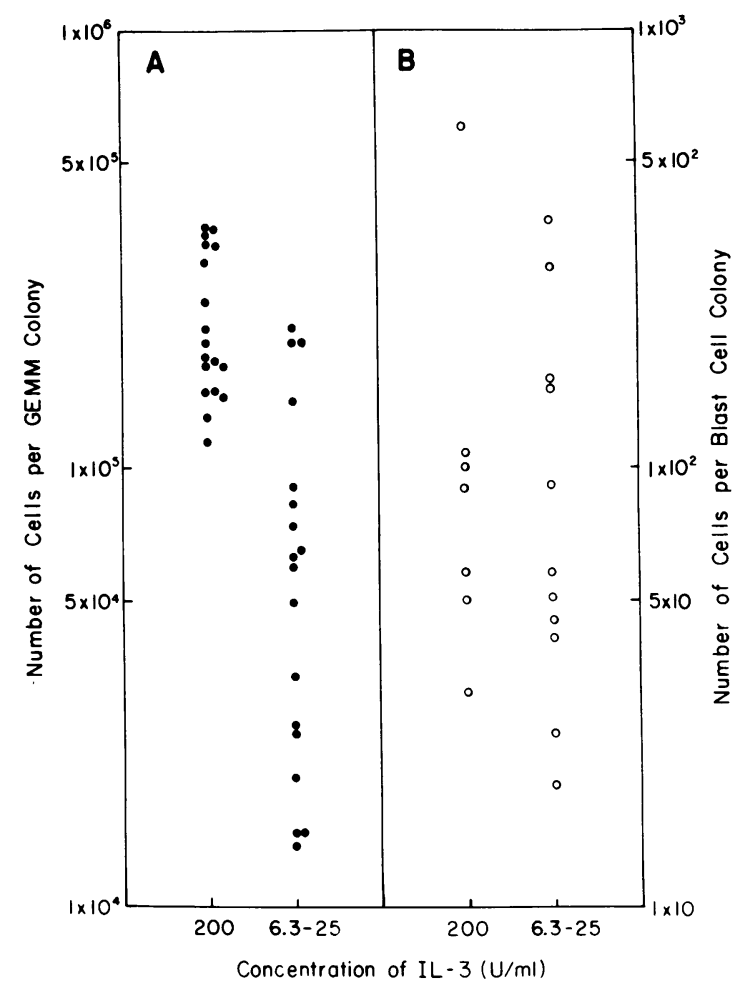

Figure 1. Distributions of size of GEMM colonies ( $\bullet$ ) and blast cell colonies (O) supported by high $(200 \mathrm{U} / \mathrm{ml})$ or low $(6.3-25 \mathrm{U} / \mathrm{ml})$ concentrations of IL-3. The GEMM colonies were larger in high concentrations of IL- 3 than those in low concentrations $(P<0.001$ by Wilcoxon rank-sum test). There was no significant difference between the sizes of blast cell colonies supported by high or low concentrations of IL-3. 
complete culture medium for analysis of secondary colony formation. As shown in Table II, blast cell colonies grown in the presence of high $(200 \mathrm{U} / \mathrm{ml})$ and low $(25 \mathrm{U} / \mathrm{ml})$ IL-3 revealed variable replating efficiencies for different single and multilineage colonies. Together the data presented in Tables I and II and Fig. 1 suggest that the process of blast cell colony development is relatively sensitive to IL-3 and requires a small amount of IL-3, whereas the process of colony development from a blast cell colony to a multilineage colony requires a larger amount of IL-3.

Repeated addition of $I L-3$. We tested the above notion using a different experimental approach. We previously demonstrated that new blast cell colonies continue to appear and grow with relatively constant cell doubling time when spleen cells of 5 FU-treated mice were cultured (8). These data indicated that multipotential progenitors are dormant in cell-cycle and begin to divide randomly. The repeated addition experiment consisted of one control and two experimental groups of quadruplicate dishes, each containing $6 \times 10^{5}$ spleen cells of 5-FU-treated mice per dish. The control group was our standard culture (7) and contained $200 \mathrm{U} / \mathrm{ml}$ of IL-3 added on day 0 of incubation. The two experimental groups received $20 \mathrm{U} / \mathrm{ml}$ of IL-3 on day 0 and either 200 or $20 \mathrm{U} / \mathrm{ml}$ of IL-3 on day 7 of incubation. The colonies were counted on day 16 of incubation except for blast cell colonies, which were followed until day 20 . The design of the experiments and the results are presented in Table III. Fewer GMM and GEMM colonies were supported by $20 \mathrm{U} / \mathrm{ml}$ IL-3 than by $200 \mathrm{U} / \mathrm{ml}$ IL-3 added on day 7 . This result suggested that multilineage colony formation requires high concentrations of IL-3. While there was some delay in the appearance of blast cell colonies in the experimental groups, the total numbers of blast cell colonies in these groups were comparable to the control group. The blast cell colonies seen between day 16 and day 20 probably represented late-emerging blast cell colonies $(7,8)$. These data indicate that $20 \mathrm{U} / \mathrm{ml} \mathrm{IL-3}$ is sufficient to support blast cell colony formation.

Culture system that favors blast cell colony formation by cells of normal mice. Cell-cycle dormancy and the ability to proliferate in low concentrations of IL-3 raised the possibility of the development of selective culture conditions for blast cell colonies. Consequently we plated $1 \times 10^{6}$ spleen cells from normal mice in the presence of 30,5 , or $2 \%$ FCS in the absence of EP and
IL-3. On day 7, $20 \mathrm{U}$ of IL-3 in $0.1 \mathrm{ml} \alpha$-medium was layered over each dish. Blast cell colonies and GM colonies and clusters ( $<50$ cells) developed (Table IV). Very infrequently small mast cell colonies and immature GMM colonies (11) were seen. Most of the GM colonies and clusters were macrophage in nature. A representative blast cell colony seen in cultures with 5\% FCS is shown in Fig. $2 A$. On days 16-20, blast cell colonies were counted and the number of cells in each colony estimated. The individual blast cell colonies were then replated into cultures containing $200 \mathrm{U} / \mathrm{ml} \mathrm{IL-3}$ and $2 \mathrm{U} / \mathrm{ml} \mathrm{EP}$. The number of GM colonies and clusters could be decreased by reducing the concentration of FCS (Table IV). Reduction in FCS and supplementation of the culture medium with transferrin, lecithin, cholesterol, and sodium selenite did not affect blast cell colony formation. The information on colony size and the replating capabilities of the blast cell colonies grown in the presence of 2 or $5 \%$ FCS and with delayed addition of $20 \mathrm{U} / \mathrm{ml} \mathrm{IL-3} \mathrm{is} \mathrm{pre-}$ sented in Table V. Varying but high replating efficiencies are shown. The secondary colonies included some multilineage colonies such as GEMM colonies. A representative multilineage colony seen in secondary culture is shown in Fig. $2 \mathrm{~B}$. The size and composition of the multilineage colonies seen in replating experiments is presented in Table VI. The sizes and types of these colonies were comparable to those present in standard serum-containing cultures (7).

\section{Discussion}

Several laboratories have attempted purification of murine and human progenitors. Some used combinations of physicochemical cell separation techniques (16-19) and others used single or combinations of monoclonal antibodies (20-23). We have developed murine and human blast cell colony assays that provide highly enriched cell populations of hemopoietic progenitors (1, 24). A major drawback in the identification of blast cell colonies in culture is the coexistence of macroscopic colonies derived from maturer progenitors. This is a particularly difficult problem in cultures of human cells, since 5-FU cannot be used to enrich for early progenitors. In the current study, we have described a culture system that favors murine blast cell colony formation based on biological differences between early and late hemo-

Table II. Replating Efficiencies of Blast Cell Colonies

\begin{tabular}{|c|c|c|c|c|c|c|c|c|c|c|}
\hline & \multicolumn{9}{|c|}{ Number of secondary colonies/blast cell colony } & \multirow{2}{*}{$\begin{array}{l}\text { Total replating } \\
\text { efficiency }\end{array}$} \\
\hline & GM & B & $\mathbf{M}$ & EM & GMM & GEM & GEMM & MAST & Total & \\
\hline & & & & & & & & & & $\%$ \\
\hline \multicolumn{11}{|c|}{ IL-3 (200 U/ml) } \\
\hline BL $(31)^{*}$ & 10 & 0 & 0 & 0 & 0 & 0 & 0 & 0 & 10 & 32 \\
\hline BL (58) & 4 & 0 & 0 & 0 & 0 & 0 & 0 & 0 & 4 & 7 \\
\hline BL (101) & 5 & 0 & 1 & 0 & 2 & 0 & 1 & 0 & 9 & 9 \\
\hline BL (108) & 32 & 0 & 1 & 0 & 1 & 4 & 2 & 0 & 40 & 37 \\
\hline \multicolumn{11}{|c|}{ IL-3 $(25 \mathrm{U} / \mathrm{ml})$} \\
\hline BL (41) & 4 & 10 & 0 & 1 & 0 & 0 & 0 & 1 & 16 & 39 \\
\hline BL (45) & 13 & 0 & 0 & 0 & 0 & 1 & 1 & 4 & 19 & 42 \\
\hline BL (51) & 28 & 1 & 1 & 2 & 0 & 3 & 3 & 5 & 43 & 84 \\
\hline BL (58) & 8 & 0 & 0 & 0 & 0 & 0 & 0 & 0 & 8 & 14 \\
\hline
\end{tabular}

Supported by 200 or $25 \mathrm{U} / \mathrm{ml} \mathrm{IL-3} \mathrm{derived} \mathrm{from} \mathrm{the} \mathrm{spleens} \mathrm{of} \mathrm{5-FU-treated} \mathrm{mice.} \mathrm{Total} \mathrm{cell} \mathrm{count} \mathrm{of} \mathrm{blast} \mathrm{cell} \mathrm{colonies.}$ 
Table III. Effects of Repeated Addition of IL-3 on Colony Formation from the Spleen Cells of 5-FU-treated Mice*

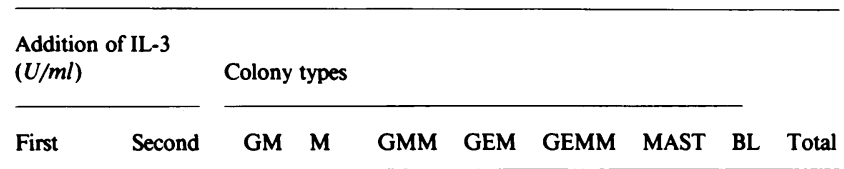

\section{Control}

200

$\begin{array}{lllllllll}0 & 14 & 17 & 9 & 1 & 15 & 2 & 6 & 64\end{array}$

Exp. 1

$\begin{array}{llllllllll}20 & 200 & 9 & 14 & 8 & 1 & 9 & 3 & 9 & 53\end{array}$

Exp. 2

$\begin{array}{llllllllll}20 & 20 & 5 & 9 & 1 & 0 & 2 & 0 & 8 & 25\end{array}$

* Numbers of colonies were derived from $2.4 \times 10^{6}$ cells in four dishes.
Table IV. Effects of Various Concentrations of FCS on Colony Formation from the Spleens of Normal Mice Supported by Delayed Addition of $20 \mathrm{U} / \mathrm{ml} \mathrm{IL-3*}$

\begin{tabular}{cccc}
\hline & GM & \\
\cline { 2 - 3 } FCS & Colonies & Clusters & BL \\
\hline$\%$ & & & \\
30 & $18 \pm 1$ & $53 \pm 6$ & $2 \pm 2$ \\
5 & $8 \pm 3$ & $18 \pm 5$ & $1 \pm 1$ \\
2 & $2 \pm 2$ & $13 \pm 5$ & $2 \pm 2$ \\
\hline
\end{tabular}

* Data represent the mean \pm SD of eight cultures containing $1 \times 10^{6}$ cells/dish.

poietic progenitors. The premises for the assay system are: $(a)$ primitive hemopoietic progenitors are dormant in cell cycle; whereas, maturer progenitors are more actively engaged in cell division; $(b)$ the dormant stem cells do not require the presence

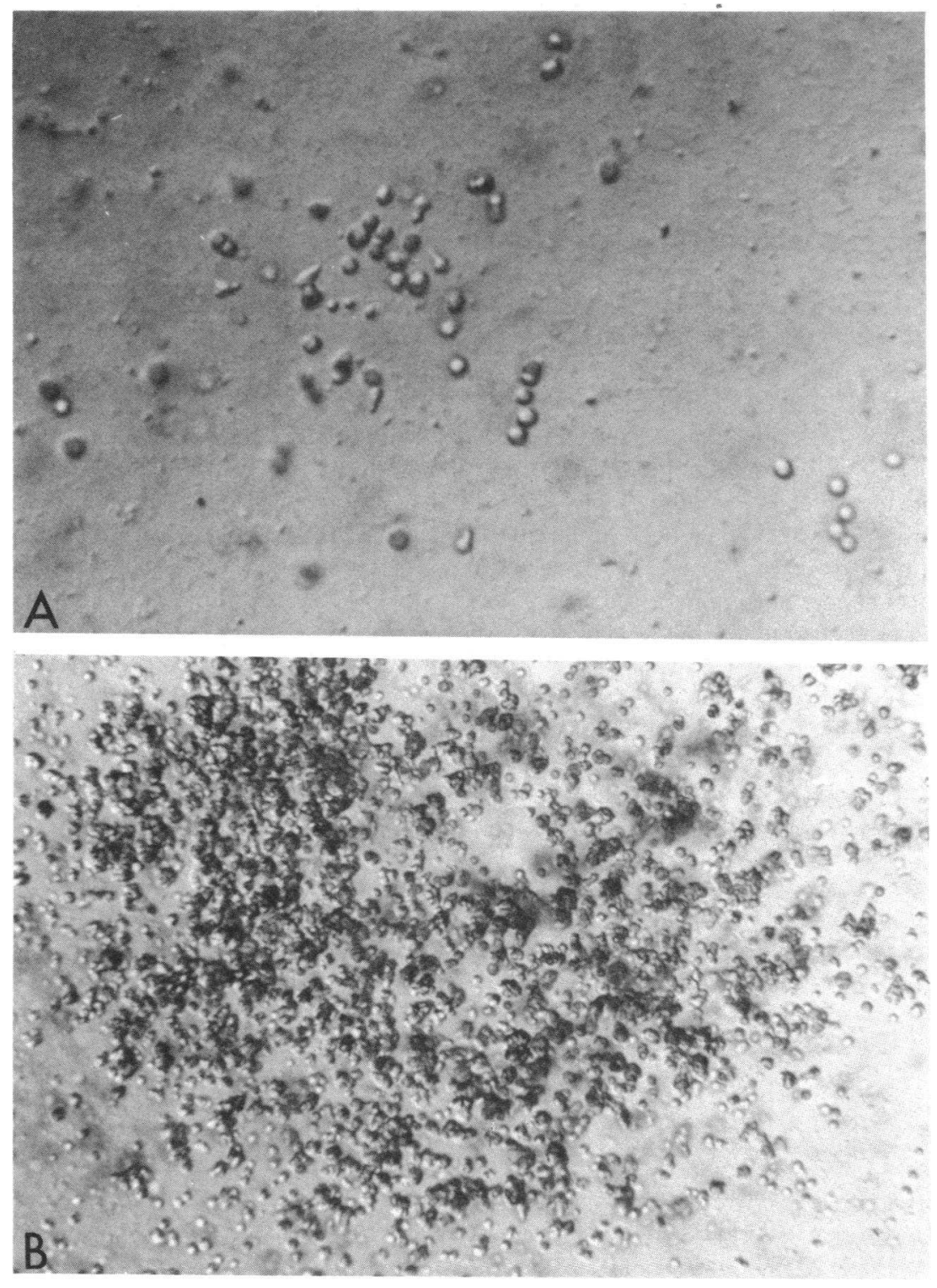

Figure 2. In situ appearance of a representative primary blast cell colony supported by $20 \mathrm{U} / \mathrm{ml}$ IL-3 that was added on day 7 of culture, and a representative multilineage colony seen in the replating experiment (colony 3 , Table VI). 
Table V. Results of Replating Experiments of Blast Cell Colonies Supported by Delayed Addition of $20 \mathrm{U} / \mathrm{ml} \mathrm{IL-3}$ in Cultures Containing Low Concentrations of FCS

\begin{tabular}{|c|c|c|c|c|c|c|c|c|c|c|c|c|}
\hline \multirow{2}{*}{$\begin{array}{l}\text { Colony } \\
\text { number* }\end{array}$} & \multirow{2}{*}{$\begin{array}{l}\text { Day of } \\
\text { harvest }\end{array}$} & \multirow{2}{*}{$\begin{array}{l}\text { Number of cells } \\
\text { per colony }\end{array}$} & \multicolumn{9}{|c|}{ Number of secondary colonies per blast cell colony } & \multirow{2}{*}{$\begin{array}{l}\text { Total replating } \\
\text { efficiency }\end{array}$} \\
\hline & & & GM & B & $\mathbf{M}$ & EM & GMM & GEM & GEMM & MAST & Total & \\
\hline & & & & & & & & & & & & $\%$ \\
\hline 1 & 16 & 46 & 27 & 0 & 2 & 0 & 0 & 0 & 0 & 0 & 29 & 63 \\
\hline 2 & 17 & 33 & 25 & 0 & 0 & 0 & $\mathbf{0}$ & 0 & 0 & 0 & 25 & 76 \\
\hline 3 & 17 & 40 & 3 & 14 & 3 & 13 & $\mathbf{0}$ & 1 & 2 & 1 & 37 & 93 \\
\hline 4 & 17 & 55 & 23 & 0 & 0 & 0 & 0 & 0 & 0 & 2 & 25 & 45 \\
\hline 5 & 17 & 59 & 17 & 2 & 1 & 2 & 0 & 0 & 2 & 1 & 25 & 42 \\
\hline 6 & 18 & 46 & 2 & 0 & 0 & 0 & 0 & 0 & 0 & 0 & 2 & 4 \\
\hline 7 & 19 & 89 & 15 & 3 & 0 & 4 & 0 & 1 & 2 & 16 & 41 & 46 \\
\hline 8 & 20 & 31 & 5 & 1 & 4 & 0 & 0 & 0 & 0 & 4 & 14 & 45 \\
\hline 9 & 20 & 52 & 3 & 0 & 0 & 0 & 0 & 0 & 0 & 1 & 4 & 8 \\
\hline 10 & 16 & 101 & 46 & 0 & 0 & 0 & 0 & 0 & 0 & 1 & 47 & 47 \\
\hline 11 & 16 & 113 & 81 & 1 & 4 & 1 & 1 & 3 & 6 & 2 & 99 & 88 \\
\hline 12 & 16 & 159 & 64 & 0 & 0 & 0 & 0 & 1 & 0 & 2 & 67 & 42 \\
\hline 13 & 18 & 33 & 11 & 2 & 1 & 2 & 0 & 2 & 0 & 1 & 19 & 58 \\
\hline 14 & 18 & 36 & 5 & 0 & 3 & 2 & 0 & 0 & 1 & 3 & 14 & 39 \\
\hline
\end{tabular}

Spleen cells of normal mice were cultured at $1 \times 10^{6}$ cells/ml. * Blast cell colonies (Nos. 1-9) were derived from cultures containing $2 \%$ FCS, and the remaining colonies (Nos. 10-14) were harvested from cultures containing 5\% FCS.

of IL-3 and require only small amounts of IL-3 when activated to cell division; whereas, later progenitors require a larger amount of IL-3; and $(c)$ the maturer progenitors require constant availability of specific colony-stimulating factors for their survival, and do not form colonies in the absence of these factors at low serum concentrations. This assay consisting of delayed addition of low concentrations of IL-3 in low serum cultures provided a simple culture system for blast cell colonies that retained high replating abilities. We are currently developing a similar culture system for human primitive progenitors.

IL-3 has been shown to support proliferation and differentiation of multipotent progenitors, as well as progenitors that are committed to single lineage expression such as megakaryocyte and macrophage $(7,25-28)$. We have shown that IL-3 does not stimulate stem cells in $\mathrm{G}_{0}$ state to begin active cell proliferation, but rather provides a permissive milieu for the continued proliferation of early hemopoietic progenitors (7). The various types of colony-stimulating activities assigned to IL-3 thus appear compatible with the permissive role of IL-3 in support of the intrinsic stochastic differentiation of hemopoietic stem cells. In this paper, we presented evidence suggesting that sensitivities of multipotent progenitors to IL-3 may decline as these cells differentiate in culture. If the activities of IL-3 on hemopoietic progenitors are mediated by receptors, it may suggest expression of receptors with lower affinities to IL-3 or a declining number of IL-3 receptors during stem cell differentiation. Receptor models similar to the latter type have been proposed by Till (29) and Iscove et al. (30). Alternatively, early progenitors may have more efficient transduction of the growth signal provided by IL-3.

Table VI. Size and Composition of Representative Multilineage Colonies Obtained by Replating Experiments of Blast Cell Colonies Supported by Delayed Addition of $20 \mathrm{U} / \mathrm{ml} \mathrm{IL-3}$

\begin{tabular}{|c|c|c|c|c|c|c|c|c|c|}
\hline \multirow[b]{2}{*}{$\begin{array}{l}\text { Colony } \\
\text { number }\end{array}$} & \multirow[b]{2}{*}{$\begin{array}{l}\text { Day of } \\
\text { analysis }\end{array}$} & \multirow[b]{2}{*}{$\begin{array}{l}\text { Number of cells } \\
\text { per colony }\end{array}$} & \multicolumn{6}{|c|}{ Differential counts* (\%) } & \multirow[b]{2}{*}{ Lineage } \\
\hline & & & $\mathbf{n}$ & m & mast & e & $\mathbf{E}$ & $\mathbf{M}$ & \\
\hline 1 & 10 & 83,000 & 7.4 & 3.0 & 22.0 & 0 & 65.8 & 1.8 & nmmastEM \\
\hline 2 & 10 & 56,000 & 1.2 & 4.8 & 51.0 & 0 & 40.2 & 2.8 & nmmastEM \\
\hline 3 & 10 & 49,000 & 0.4 & 3.0 & 32.4 & 0 & 64.2 & 0 & nmmastE \\
\hline 4 & 10 & 40,000 & 0 & 12.4 & 40.0 & 0 & 46.6 & 1.0 & mmastEM \\
\hline 5 & 10 & 7,100 & 0 & 30.0 & 44.2 & 0 & 20.4 & 5.4 & mmastEM \\
\hline 6 & 10 & 5,000 & 13.8 & 11.2 & 74.6 & 0 & 0 & 0.4 & nmmastM \\
\hline 7 & 10 & 6,000 & 48.4 & 51.0 & 0 & 0.6 & 0 & 0 & nme \\
\hline 8 & 8 & 2,500 & 39.2 & 5.8 & 0 & 55.0 & 0 & 0 & nme \\
\hline
\end{tabular}

* Differential counting was carried out on 500 cells. Abbreviation for lineages: $\mathbf{n}$, neutrophils; m, macrophages; mast, mast cells; e, eosinophils; E, erythrocytes; and M, megakaryocytes. 


\section{Acknowledgments}

We would like to thank Mrs. Lobelia A. Avila and Mrs. Geneva Winkler for excellent technical assistance, Dr. Pamela N. Pharr, Dr. Alan J. Gross, and Mrs. Anne G. Leary for advice on the manuscript, and Ms. P. Linda Skipper for assistance in the preparation of this manuscript.

This work was supported by National Institutes of Health grant AM32294, and by the Veterans Administration. This work was also supported in part by the National Cancer Institute under contract N01C0-75380 with Litton Bionetics, Inc., Kensington, MD. The contents of this publication do not necessarily reflect the views or policies of the Department of Health and Human Services, nor does mention of trade names, commercial products, or organizations imply endorsement by the U. S. government. Dr. Ogawa is a VA Medical Investigator.

\section{References}

1. Nakahata, T., and M. Ogawa. 1982. Identification in culture of a class of hemopoietic colony-forming units with extensive capability to self-renew and generate multipotential colonies. Proc. Natl. Acad. Sci. USA. 79:3843-3847.

2. Nakahata, T., A. J. Gross, and M. Ogawa. 1982. A stochastic model of self-renewal and commitment to differentiation of the primitive hemopoietic stem cells in culture. J. Cell Physiol. 113:455-458.

3. Till, J. E., E. A. McCulloch, and L. Siminovitch. 1964. A stochastic model of stem cell proliferation, based on the growth of spleen colony forming cells. Proc. Natl. Acad. Sci. USA. 51:29-36.

4. Suda, T., J. Suda, and M. Ogawa. 1983. Single-cell origin of mouse hemopoietic colonies expressing multiple lineages in variable combinations. Proc. Natl. Acad. Sci. USA. 80:6689-6693.

5. Suda, T., J. Suda, and M. Ogawa. 1984. Disparate differentiation in mouse hemopoietic colonies derived from paired progenitors. Proc. Natl. Acad. Sci. USA. 81:2520-2524.

6. Suda, J., T. Suda, and M. Ogawa. 1984. Analysis of differentiation of mouse hemopoietic stem cells in culture by sequential replating of paired progenitors. Blood. 64:393-399.

7. Suda, T., J. Suda, M. Ogawa, and J. N. Ihle. 1985. Permissive role of interleukin 3 (IL-3) in proliferation and differentiation of multipotential hemopoietic progenitors in culture. J. Cell Physiol. 124:182-190.

8. Suda, T., J. Suda, and M. Ogawa. 1983. Proliferative kinetics and differentiation of murine blast cell colonies in culture: evidence for variable $\mathrm{G}_{0}$ periods and constant doubling rates of early pluripotent hemopoietic progenitors. J. Cell Physiol. 117:308-318.

9. Koike, K., E. R. Stanley, J. N. Ihle, and M. Ogawa. 1986. Macrophage colony formation supported by purified CSF-1 and/or IL-3 in serum-free culture: evidence for hierarchical difference in macrophage colony-forming cells. Blood. In press.

10. Ihle, J. N., J. Keller, L. Henderson, F. Klein, and E. Palaszynski. 1982. Procedures for the purification of interleukin 3 to homogeneity. J. Immunol. 129:2431-2436.

11. Hodgson, G. S., and T. R. Bradley. 1979. Properties of haematopoietic stem cells surviving 5-fluorouracil treatment: evidence for a pre-CFU-S cell? Nature (Lond.). 281:381-382.

12. Nakahata, T., and M. Ogawa. 1982. Clonal origin of murine hemopoietic colonies with apparent restriction to granulocyte-macrophage-megakaryocyte (GMM) differentiation. J. Cell Physiol. 111:239246.

13. Iscove, N. N., F. Sieber, and K. H. Winterhalter. 1974. Erythroid colony formation in cultures of mouse and human bone marrow. Analysis of the requirement for erythropoietin by gel filtration and affinity chromatography on agarose-concanavalin A. J. Cell Physiol. 83:309-320.

14. Nakahata, T., S. S. Spicer, J. R. Cantey, and M. Ogawa. 1982.
Clonal assay of mouse mast cell colonies in methylcellulose culture. Blood. 60:352-361.

15. Axelrad, A. A., A. Burgess, N. N. Iscove, and G. Wagemaker. 1981. Culture of hematopoietic cells: workshop report. In Control of Cellular Division and Development, Part B. D. Cunningham, E. Goldwasser, J. Watson, and C. F. Fox, editors. Alan R. Liss, Inc., New York. 421-425.

16. Williams, N., H. Jackson, and P. Meyers. 1979. Isolation of pluripotent hemopoietic stem cells and clonable precursor cells of erythrocytes, granulocytes, macrophages and megakaryocytes from mouse bone marrow. Exp. Hematol. 7:524-534.

17. Inoue, T., A. L. Carsten, E. P. Cronkite, and J. E. T. Kelley. 1981. Separation and concentration of murine hematopoietic stem cells $\left(\mathrm{CFU}_{\mathrm{s}}\right)$ using a combination of density gradient sedimentation and counterflow centrifugal elutriation. Exp. Hematol. 9:563-572.

18. Nicola, N. A., D. Metcalf, H. von Melchner, and A. W. Burgess. 1981. Isolation of murine fetal hemopoietic progenitor cells and selective fractionation of various erythroid precursors. Blood. 58:376-386.

19. Visser, J. W. M., J. G. J. Bauman, A. H. Mulder, J. F. Eliason, and A. M. de Leeuw. 1984. Isolation of murine pluripotent hemopoietic stem cells. J. Exp. Med. 59:1576-1590.

20. Beverley, P. C. L., D. Linch, and D. Delia. 1980. Isolation of human haematopoietic progenitor cells using monoclonal antibodies. Nature (Lond.). 287:332-333.

21. Griffin, J. D., R. P. Beveridge, and S. F. Schlossman. 1982. Isolation of myeloid progenitor cells from peripheral blood of chronic myelogenous leukemia patients. Blood. 60:30-37.

22. Civin, C. I., L. C. Strauss, C. Brovall, M. J. Fackler, J. F. Schwartz, and J. H. Shaper. 1984. Antigenic analysis of hematopoiesis. III. A hematopoietic progenitor cell surface antigen defined by a monoclonal antibody raised against KG-1a cells. J. Immunol. 133:157-165.

23. Koizumi, S., R. L. Fine, G. A. Curt, J. D. Griffin, and B. A. Chabner. 1985. Enrichment of myeloid progenitor cells from normal human bone marrow using an immune-rosette technique. Exp. Hematol. 13:560-565.

24. Nakahata, T., and M. Ogawa. 1982. Hemopoietic colony-forming cells in umbilical cord blood with extensive capability to generate monoand multipotential hemopoietic progenitors. J. Clin. Invest. 70:13241328.

25. Ihle, J. N., J. Keller, S. Oroszlan, L. E. Henderson, T. D. Copeland, F. Fitch, M. B. Prystowsky, E. Goldwasser, J. W. Schrader, E. Palaszynski, M. Dy, and B. Lebel. 1983. Biologic properties of homogeneous interleukin 3. I. Demonstration of WEHI-3 growth factor activity, mast cell growth factor activity, P cell-stimulating factor activity, colony-stimulating factor activity and histamine-producing cell-stimulating factor activity. J. Immunol. 131:282-287.

26. Prystowsky, M. B., G. Otten, M. F. Naujokas, J. Vardiman, J. N. Ihle, E. Goldwasser, and F. W. Fitch. 1984. Multiple hemopoietic lineages are found after stimulation of mouse bone marrow precursor cells with interleukin 3. Am. J. Pathol. 117:171-179.

27. Quesenberry, P. J., J. N. Ihle, and E. McGrath. 1985. The effect of interleukin 3 and GM-CSA-2 on megakaryocyte and myeloid clonal colony formation. Blood. 65:214-217.

28. Rennick, D. M., F. D. Lee, T. Yokota, K. Arai, H. Cantor, and G. J. Nabel. 1985. A cloned MCGF cDNA encodes a multilineage hematopoietic growth factor: multiple activities of interleukin 3. J. Immunol. 134:910-914.

29. Till, J. E. 1976. Regulation of hemopoietic stem cells. In Stem Cells of Renewing Cell Populations. A. B. Cairnie, P. K. Lala, and D. G. Osmond, editors. Academic Press, Inc., New York. 143-155.

30. Iscove, N. N., C. A. Roitsch, N. Williams, and L. J. Guilbert. 1982. Molecules stimulating early red cell, granulocyte, macrophage, and megakaryocyte precursors in culture: similarity in size, hydrophobicity, and charge. J. Cell Physiol. (Suppl. 1):65-78. 